\title{
Association Analysis of Monocyte Chemotactic Protein-3 (MCP3) Polymorphisms with Asthmatic Phenotypes
}

\author{
Byung Lae Park, Lyoung Hyo Kim, Yoo Hyun Choi, Hyun Sub Cheong, Hae-Sim Park ${ }^{\dagger}$, Soo-Jong Hong ${ }^{\dagger}$, \\ Byoung Whui Choi ${ }^{\dagger}$, June-Hyuk Lee ${ }^{\dagger}$, Soo-Taek Uh ${ }^{\dagger}$, Choon-Sik Park ${ }^{\dagger} *$ and Hyoung Doo Shin \\ Department of Genetic Epidemiology, SNP Genetics, Inc., \\ 11th Floor, MaeHun B/D, 13 Chongro 4 Ga, Chongro-Gu, Seoul 110-834, Korea \\ †Asthma Genome Research Group, Soonchunhyang University Hospital, Ajuo University Hospital, \\ Ulsan University Hospital and Choong-Ang University Hospital, Korea
}

Received 16 April 2004, Accepted 29 September 2004

The monocyte chemotactic protein-3 (MCP3), on chromosome 17q11.2-q12, is a secreted chemokine, which attracts macrophages during inflammation and metastasis. In an effort to discover additional polymorphism(s) in genes whose variant(s) have been implicated in asthma, we scrutinized the genetic polymorphisms in MCP3 to evaluate it as a potential candidate gene for asthma host genetic study. By direct DNA sequencing in twenty-four individuals, we identified four sequence variants within the $3 \mathrm{~kb}$ full genome including $1,000 \mathrm{bp}$ promoter region of $M C P 3$; one in promoter region $(-420 T>C)$, three in intron $(+136 C>G,+563 C>T,+984 G>A)$ respectively. The frequencies of those four SNPs were $0.020(-420 T>C), 0.038(+136 C>G)$, $0.080(+563 C>T), 0.035(+984 G>A)$, respectively, in Korean population $(n=598)$. Haplotypes, their frequencies and linkage disequilibrium coefficients $\left(\left|D^{\prime}\right|\right)$ between SNP pairs were estimated. The associations with the risk of asthma, skin-test reactivity and total serum IgE levels were analyzed. Using statistical analyses for association of MCP3 polymorphisms with asthma development and asthma-related phenotypes, no significant signals were detected. In conclusion, we identified four genetic polymorphisms in the important MCP3 gene, but no significant associations of $M C P 3$ variants with asthma phenotypes were detected. MCP3 variation/haplotype information identified in this study will provide valuable information for future association studies of other allergic diseases.

Byung Lae Park and Lyoung Hyo Kim equally contributed to this work.

*To whom correspondence should be addressed.

Tel: 82-32-621-5105; Fax: 82-32-621-5023

Email: mdcspark@unitel.co.kr
Kewwords: Asthma, Allergic disease, $M C P 3$, Single nucleotide polymorphism

\section{Introduction}

Asthma is a common and heterogeneous respiratory disease characterized by intermittent airway obstruction and respiratory symptoms that are caused by chronic airway inflammation. The development of asthma appears to be determined by the interaction between host susceptibility and a variety of environmental exposures.

The chemokines are a family of protein mediators with potent chemoattractant activity for granulocytes, monocytes and lymphocytes (Baggiolini et al., 1994). The chemokines are generally subdivided into $\mathrm{C}-\mathrm{C}$ chemokines having 2 adjacent cysteine residues and into $\mathrm{C}-\mathrm{X}-\mathrm{C}$ chemokines, in which the cysteines are separated by 1 amino acid residue. MCP3 (MIM\# 158106) has been reported to interact with several C-C chemokine receptors, which can be simultaneously or selectively expressed on leukocyte subpopulations (BenBaruch et al., 1995). The diversity of MCP3 target cell types, as well as the capacity of MCP3 to desensitize leukocyte responses to other $\mathrm{C}-\mathrm{C}$ chemokines, suggested that $\mathrm{MCP} 3$ may interact with multiple $\mathrm{C}-\mathrm{C}$ chemokine receptors $(\mathrm{Xu}$ et al., 1995). MCP3 mRNA was significantly elevated in the bronchial mucosa of atopic and non-atopic asthmatics (Powell et al., 1996) (Humbert et al., 1997), and elevated MCP3 expression was associated with increased numbers of bronchial mucosal eosinophils in the atopic asthmatic patients (Powell et al., 1996). Moreover, MCP3 was significantly increased in bronchoalveolar lavage fluid obtained from asthmatics (Rojas-Ramos et al., 2003), and allergen challenge induced the expression of MCP3 predominantly in the airway 
mucosa of ovalalbumin challenged experimental asthma epithelium (Stafford et al., 1997).

The $M C P 3$, on chromosome17q11.2-q12, is a part of cluster of $\mathrm{C}-\mathrm{C}$ chemokine family members on chromosome 17q. Despite the characterization of the structure and the sequencing of the $\mathrm{C}-\mathrm{C}$ chemokines, little is known about genetic polymorphisms and possible involvement in asthma.

In this study, we scrutinized the genetic polymorphisms in $M C P 3$ to evaluate it as a potential candidate gene for asthma host genetic study. We performed extensive screening of $M C P 3$ by direct sequencing to detect polymorphisms and statistical analysis to examine the genetic effects on asthma and related phenotypes. Here, we present four genetic polymorphisms found in $M C P 3$ and the results of an association study in a Korean asthma cohort.

\section{Materials and Methods}

Subjects Subjects were recruited from the Asthma Genome Research Center that consists of four tertiary hospitals in Korea (Soonchunhyang University Hospital, Ajuo University Hospital, Ulsan University Hospital, and Choong-Ang University Hospital). The DNA was collected from blood samples as described in Kim et al. (2003). Ethical approvals were obtained from the institutional review board of each hospital. All patients had the clinical symptoms and the physical examinations compatible with asthma. Each patient showed airway reversibility as documented by an inhalant bronchodilator-induced improvement of more than $15 \%$ of forced expiratory volume in one second (FEV1) and/or an airway hyperreactivity of less than $10 \mathrm{mg} / \mathrm{ml}$ of methacholine. Normal subjects were recruited from spouses of the patients and the general population who answered negatively to a screening questionnaire for respiratory symptoms and had FEV1 greater than $75 \%$ predicted, the provocation concentration causing a fall in the FEV1 of $20 \%$ (PC20) by methacholine greater than $10 \mathrm{mg} / \mathrm{ml}$, and normal finding on a simple chest radiogram. Total IgE was measured using the UniCAP system (Pharmacia Diagnostics, Uppsala, Sweden). Atopy was defined as having wheal reaction by allergen extract equal to or greater than that by histamine $(1 \mathrm{mg} / \mathrm{ml})$ or $3 \mathrm{~mm}$ in diameter. The clinical parameters are summarized in Table 1.

Sequencing analysis of the human MCP3 gene We have sequenced whole gene $(\sim 3 \mathrm{~kb})$, including promoter region, to discover single nucleotide polymorphisms (SNPs) in 24 Korean unregulated individual DNA samples using the ABI PRISM 3700 DNA analyzer (Applied Biosystems, Foster City, USA). Eight primer sets for the amplification and sequencing analysis were designed based on GenBank sequences (Ref. Genome seq.; NT_010799 released on Jan. 2004). Information regarding primers is available on our website (http://www.snp-genetics.com/reference/ 0503_MCP3.doc). Sequence variants were verified by chromatograms. Putative transcription factor binding site was estimated by TFSEARCH (Searching Transcription Factor Binding Sites V1.3, putative score>0.95; http://molsun1.cbrc.aist.go.jp/research/db/ TFSEARCH.html). For comparison of allele frequencies of $M C P 3$
Table 1. Clinical profiles of the study subjects

\begin{tabular}{ccc}
\hline Clinical profiles & Normal controls & Asthmatics \\
\hline No. of subjects & 148 & 450 \\
Age (mean(range) & $28.5(7-75)$ & $35.0(7-80)$ \\
Sex (male/female) & $73 / 75$ & $203 / 247$ \\
Current smoker & $30.9 \%$ & $19.4 \% *$ \\
FVC1\%, predicted $( \pm \mathrm{SD})$ & $89.2( \pm 1.7)$ & $87.7 \pm 0.7$ \\
FEV1\%, predicted $( \pm \mathrm{SD})$ & $93.5( \pm 1.2)$ & $83.2 \pm 0.9^{*}$ \\
$\mathrm{PC}_{20}$, methacholine $(\mathrm{mg} / \mathrm{mL}( \pm \mathrm{SD}))$ & $24.1( \pm 1.4)$ & $2.8 \pm 0.7^{*}$ \\
Total IgE $(\mathrm{IU} / \mathrm{mL})( \pm \mathrm{SD})$ & $212.2( \pm 41.7)$ & $537.3 \pm 52.4^{*}$ \\
Skin test positive $(\%)$ & $27(18.2 \%)$ & $255(56.7 \%)^{*}$ \\
\hline
\end{tabular}

${ }^{*} P$ value $<0.001$ for difference between asthmatics and normal controls

SNPs, which were identified in Korean population, with other major ethnic groups, we also genotyped 50 Caucasian and 50 African-American DNAs obtained from the Human Genetic Cell Repository (http://locus.umdnj.edu/nigms/).

Genotyping with fluorescence polarization detection For genotyping of polymorphic sites with our asthma study, amplifying primers and probes were designed for Taqman (Livak, 1999; Zhang and Li, 2003). Primer Express (Applied Biosystems, Foster City, USA) was used to design both the PCR primers and the MGB TaqMan probes. One allelic probe was labeled with the FAM dye and the other with the fluorescent VIC dye. PCRs were run in TaqMan Universal Master mix without UNG (Applied Biosystems) with PCR primer concentrations of $900 \mathrm{nM}$ and TaqMan MGBprobe concentrations of $200 \mathrm{nM}$. Reactions were performed in 384well format in a total reaction volume of $5 \mathrm{ml}$ using $20 \mathrm{ng}$ of genomic DNA. The plates then were placed in a thermal cycler (PE 9700, Applied Biosystems) and heated at $50^{\circ} \mathrm{C}$ for 2 min and $95^{\circ} \mathrm{C}$ for $10 \mathrm{~min}$ followed by 40 cycles of $95^{\circ} \mathrm{C}$ for $15 \mathrm{~s}$ and $60^{\circ} \mathrm{C}$ for 1 min with a final soak at $25^{\circ} \mathrm{C}$. The TaqMan assay plates were transferred to the Prism 7900HT instruments (Applied Biosystems) where the fluorescence intensity in each well of the plate was read. Fluorescence data files from each plate were analyzed by automated allele-calling software (SDS 2.1).

Statistics We examined Lewontins $\mathrm{D}\left(\left|\mathrm{D}^{\prime}\right|\right)$ and LD coefficienct $r^{2}$ between all pairs of biallelic loci (Hedrick, 1987; Hedrick and Kumar, 2001). Haplotypes of each individual were inferred using the algorithm developed by Stephens et al. (2001), which (PHASE) uses a Bayesian approach incorporating a priori expectations of haplotypic structure from population genetic and coalescent theory. Genetic effects of inferred haplotypes were analyzed in same way as SNPs. Phase probabilities of each site were calculated for each individual by this software. Genotype distribution of $M C P 3$ polymorphisms between the asthmatics and the normal subjects, means and standard deviations (SD) of phenotypes, and $P$ values were calculated by multiple regression analyses controlling age (continuous value), sex $($ male $=0$, female $=1$ ) and smoking status (non-smoker $=0$, ex-smoker $=1$, smoker $=2$ ) as covariates. 


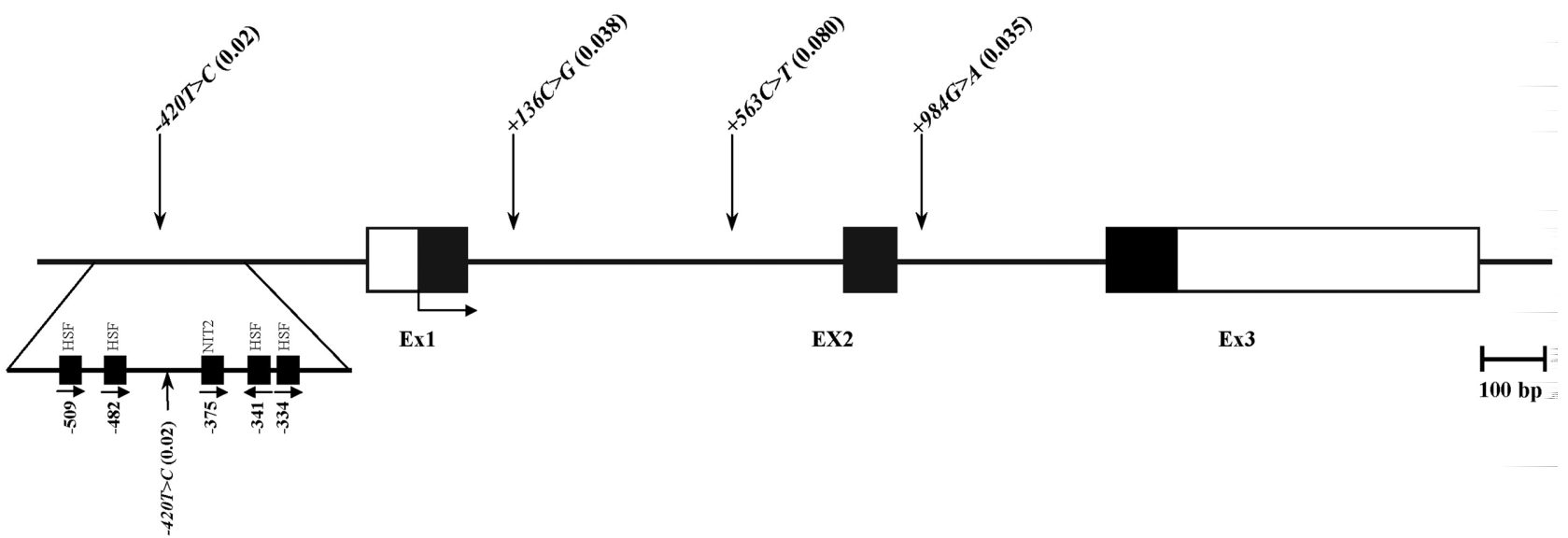

Fig. 1. Gene Map and SNPs in MCP3 on chromosome 17q11.2-q12. Coding exons are marked by black blocks and 5' and 3' UTR by white blocks. First base of translation site was denoted as nucleotide +1 . Putative transcription factor binding site is indicated (TFSEARCH Searching Transcription Factor Binding Sites V1.3. putative score $>0.95$ ).

Table 2. Novel Single nucleotide polymorphisms (SNPs) and allele frequencies of human MCP3 in Korean ( $=598$ ), African American $(\mathrm{n}=50)$ and Caucasian $(\mathrm{n}=50)$ subjects

\begin{tabular}{|c|c|c|c|c|c|c|}
\hline \multirow[b]{2}{*}{ Locus } & \multirow[b]{2}{*}{ Region } & \multirow[b]{2}{*}{ HWE* $^{*}$} & \multirow[b]{2}{*}{ Heterozygosity } & \multicolumn{3}{|c|}{ Rare allele Frequencies } \\
\hline & & & & $\begin{array}{c}\text { Korean } \\
(\mathrm{N}=598)\end{array}$ & $\begin{array}{l}\text { African American } \\
(\mathrm{N}=50)\end{array}$ & $\begin{array}{c}\text { Caucasian } \\
(\mathrm{N}=50)\end{array}$ \\
\hline$-420 T>C$ & $5^{\prime}$ & 0.291 & 0.040 & 0.020 & 0 & 0 \\
\hline$+136 C>G$ & Intron2 & 0.628 & 0.074 & 0.038 & 0 & 0 \\
\hline$+563 C>T$ & Intron2 & 0.986 & 0.147 & 0.080 & 0.040 & 0.280 \\
\hline$+984 G>A$ & Intron3 & 0.312 & 0.068 & 0.035 & 0 & 0 \\
\hline
\end{tabular}

* $P$ values of deviation from Hardy-Weinberg Equilibrium in Korean population. Additional information of primers sequences is available at http://www.snpgenetics.com/reference/ 0503_MCP3.doc

Table 3. Frequencies of haplotypes constructed in MCP3 gene in Korean $(n=598)$, African American $(n=50)$ and Caucasian ( $n=50)$ subjects

\begin{tabular}{cccccccc}
\hline & \multicolumn{4}{c}{ Locus } & \multicolumn{2}{c}{ Frequency } \\
\cline { 2 - 8 } Haplotype & $-420 T>C$ & $+136 C>G$ & $+563 C>T+984 G>A$ & $\begin{array}{c}\text { Korean } \\
(\mathrm{N}=598)\end{array}$ & $\begin{array}{c}\text { African American } \\
(\mathrm{N}=50)\end{array}$ & $\begin{array}{c}\text { Caucasian } \\
(\mathrm{N}=50)\end{array}$ \\
\hline ht1 (T-C-C-G) & $\mathrm{T}$ & $\mathrm{C}$ & $\mathrm{C}$ & $\mathrm{G}$ & 0.828 & 0.95 & 0.72 \\
ht2 (T-C-T-G) & $\mathrm{T}$ & $\mathrm{C}$ & $\mathrm{T}$ & $\mathrm{G}$ & 0.079 & 0.04 & 0.28 \\
ht3 (T-G-C-G) & $\mathrm{T}$ & $\mathrm{G}$ & $\mathrm{C}$ & $\mathrm{G}$ & 0.038 & 0 & 0 \\
ht4 (T-C-C-A) & $\mathrm{T}$ & $\mathrm{C}$ & $\mathrm{C}$ & $\mathrm{A}$ & 0.036 & 0.01 & 0 \\
ht5 (C-C-C-G) & $\mathrm{C}$ & $\mathrm{C}$ & $\mathrm{C}$ & $\mathrm{G}$ & 0.019 & 0 & 0 \\
\hline
\end{tabular}

Haplotypes were constructed by an algorithm developed by Stephens et al. (2001). MCP3- $h t 2$, - $h t 3$, - $h t 4$, and - $h t 5$ are equivalent with $M C P 3+563 C>T,+136 C>G,+984 G>A$, and $-420 T>C$.

\section{Results and Discussion}

Monocyte chemotactic protein-3 (MCP3) plays important roles in the patophysiology in atopic and non-atopic asthma (Ying et al., 1999). Elevated MCP3 mRNA expression was associated with significantly increased numbers of bronchial mucosal eosinophils in the asthmatic patients as compared to the nonasthmatic normal control subjects (Powell et al., 1996).
We identified four sequence variants within the $3 \mathrm{~kb}$ full genome including $-1,000 \mathrm{bp}$ promoter region of $M C P 3$; one in promoter region $(-420 T>C)$, three intron $(+136 C>G$, $+563 C>T,+984 G>A$ ) respectively. (see Table 2 and Fig. 1). In the estimation of putative transcription factor (TF) binding site, it was shown that four sites for heat-shock transcription factor (HSF) and one for nitrilase-2 (NIT2) (Fig. 1). However no polymorphism was identified in TF binding site of $M C P 3$. Those SNPs were genotyped in Korean asthma cohort to 
Table 4. Linkage disequilibrium coefficients $\left(\mid \mathrm{D}^{\prime}\right)$ between SNP loci in MCP3 gene.

\begin{tabular}{cccccc}
\hline \multirow{2}{*}{ Polymorphisms } & \multicolumn{4}{c}{ Linkage disequilibrium coefficients $\left(\left|\mathrm{D}^{\prime}\right|\right)$} & \\
\cline { 2 - 5 } & & $-420 T>C$ & $+136 C>G$ & $+563 C>T$ & $+984 G>A$ \\
\hline$-420 T>C$ & & - & 1 & 1 & 1 \\
$+136 C>G$ & $r^{2}$ & 0.001 & - & 1 & 1 \\
$+563 C>T$ & 0.002 & 0.003 & - & 1 \\
$+984 G>A$ & 0.001 & 0.001 & 0.003 & - \\
\hline
\end{tabular}

Linkage disequilibrium coeffients (|D'| and $r^{2}$ ) were calculated between all pairs of biallelic loci (Hedrick and Kumar 2001; Hedrick 1987).

Table 5. Analyses of association of $M C P 3$ polymorphisms with asthma phenotypes (risk of asthma, skin-test reactivity and total serum IgE level) in a Korean asthma cohort.

\begin{tabular}{|c|c|c|c|c|c|c|c|c|c|c|c|}
\hline \multirow[b]{2}{*}{ Locus } & \multirow[b]{2}{*}{ Genotype } & \multicolumn{4}{|c|}{ Status of Asthma } & \multicolumn{4}{|c|}{ Skin-test reactivity } & \multicolumn{2}{|c|}{ Log [Total $\mathrm{IgE}]^{* * *}$} \\
\hline & & Asthmatics & Controls & $\begin{array}{c}\text { OR } \\
(95 \% \mathrm{CI})\end{array}$ & $\mathrm{P}^{*}$ & Negative & Positive & $\begin{array}{c}\text { OR } \\
(95 \% \mathrm{CI})\end{array}$ & $\mathrm{P}^{*}$ & $\underset{(m e a n \pm S D)}{\mathrm{N}}$ & $\mathrm{P}^{*}$ \\
\hline \multirow[t]{3}{*}{$-420 T>C$} & TT & $\begin{array}{c}415 \\
(95.8 \%)\end{array}$ & $\begin{array}{c}156 \\
(96.9 \%)\end{array}$ & \multirow{3}{*}{$\begin{array}{c}1.16 \\
(0.4-3.35)\end{array}$} & \multirow{3}{*}{0.78} & $\begin{array}{c}309 \\
(96.6 \%)\end{array}$ & $\begin{array}{c}215 \\
(95.6 \%)\end{array}$ & \multirow{3}{*}{$\begin{array}{c}1.6 \\
(0.48-5.36)\end{array}$} & & $\begin{array}{c}405 \\
(2.26 \pm 0.62)\end{array}$ & \multirow{3}{*}{0.29} \\
\hline & $\mathrm{CT}$ & $18(4.2 \%)$ & $4(2.5 \%)$ & & & $\begin{array}{c}10 \\
(3.1 \%)\end{array}$ & $\begin{array}{c}10 \\
(4.4 \%)\end{array}$ & & 0.44 & $\begin{array}{c}18 \\
(2.19 \pm 0.74)\end{array}$ & \\
\hline & $\mathrm{CC}$ & - & $1(0.6 \%)$ & & & $\begin{array}{c}1 \\
(0.3 \%)\end{array}$ & $\cdot$ & & & $\cdot$ & \\
\hline \multirow[t]{3}{*}{$+136 C>G$} & $\mathrm{CC}$ & $\begin{array}{c}390 \\
(92 \%)\end{array}$ & $\begin{array}{c}153 \\
(93.3 \%)\end{array}$ & \multirow{3}{*}{$\begin{array}{c}1.45 \\
(0.64-3.31)\end{array}$} & \multirow{3}{*}{0.38} & $\begin{array}{c}296 \\
(92.5 \%)\end{array}$ & $\begin{array}{c}200 \\
(91.7 \%)\end{array}$ & \multirow{3}{*}{$\begin{array}{c}0.8 \\
(0.27-2.35)\end{array}$} & & $\begin{array}{c}405 \\
(2.26 \pm 0.62)\end{array}$ & \multirow{3}{*}{0.78} \\
\hline & CG & $\begin{array}{c}34 \\
(8 \%)\end{array}$ & $\begin{array}{c}11 \\
(6.7 \%)\end{array}$ & & & $\begin{array}{c}24 \\
(7.5 \%)\end{array}$ & $\begin{array}{c}18 \\
(8.3 \%)\end{array}$ & & 0.68 & $\begin{array}{c}18 \\
(2.19 \pm 0.74)\end{array}$ & \\
\hline & GG & - & - & & & . & . & & & . & \\
\hline \multirow[t]{3}{*}{$+563 C>T$} & $\mathrm{CC}$ & $\begin{array}{c}359 \\
(84.9 \%)\end{array}$ & $\begin{array}{c}136 \\
(84.5 \%)\end{array}$ & \multirow{3}{*}{$\begin{array}{c}1.09 \\
(0.63-1.87)\end{array}$} & \multirow{3}{*}{0.76} & $\begin{array}{c}270 \\
(84.6 \%)\end{array}$ & $\begin{array}{c}183 \\
(84.7 \%)\end{array}$ & \multirow{3}{*}{$\begin{array}{c}1.94 \\
(0.9-4.2)\end{array}$} & & $\begin{array}{c}352 \\
(2.25 \pm 0.63)\end{array}$ & \multirow{3}{*}{0.91} \\
\hline & $\mathrm{CT}$ & $\begin{array}{c}61 \\
(14.4 \%)\end{array}$ & $\begin{array}{c}24 \\
(14.9 \%)\end{array}$ & & & $\begin{array}{c}45 \\
(14.1 \%)\end{array}$ & $\begin{array}{c}33 \\
(15.3 \%)\end{array}$ & & 0.09 & $\begin{array}{c}58 \\
(2.31 \pm 0.65)\end{array}$ & \\
\hline & $\mathrm{TT}$ & $\begin{array}{c}3 \\
(0.7 \%)\end{array}$ & $\begin{array}{c}1 \\
(0.6 \%)\end{array}$ & & & $\begin{array}{c}4 \\
(1.3 \%)\end{array}$ & $\cdot$ & & & $\begin{array}{c}3 \\
(2.05 \pm 0.49)\end{array}$ & \\
\hline \multirow[t]{3}{*}{$+984 G>A$} & GG & $\begin{array}{c}406 \\
(93.3 \%)\end{array}$ & $\begin{array}{c}153 \\
(93.3 \%)\end{array}$ & \multirow{3}{*}{$\begin{array}{c}0.73 \\
(0.35-1.51)\end{array}$} & \multirow{3}{*}{0.39} & $\begin{array}{c}301 \\
(93.2 \%)\end{array}$ & $\begin{array}{c}210 \\
(92.9 \%)\end{array}$ & \multirow{3}{*}{$\begin{array}{c}1.61 \\
(0.57-4.59)\end{array}$} & & $\begin{array}{c}396 \\
(2.24 \pm 0.63)\end{array}$ & \multirow{3}{*}{0.26} \\
\hline & AG & $\begin{array}{c}28 \\
(6.4 \%)\end{array}$ & $\begin{array}{c}10 \\
(6.1 \%)\end{array}$ & & & $\begin{array}{c}20 \\
(6.2 \%)\end{array}$ & $\begin{array}{c}16 \\
(7.1 \%)\end{array}$ & & 0.37 & $\begin{array}{c}28 \\
(2.46 \pm 0.54)\end{array}$ & \\
\hline & AA & $\begin{array}{c}1 \\
(0.2 \%)\end{array}$ & $\begin{array}{c}1 \\
(0.6 \%)\end{array}$ & & & $\begin{array}{c}2 \\
(0.6 \%)\end{array}$ & $\cdot$ & & & $\begin{array}{c}1 \\
(2.31 \pm 0.00)\end{array}$ & \\
\hline \multirow[t]{3}{*}{$h t 1$} & $-/-$ & $\begin{array}{c}15 \\
(3.5 \%)\end{array}$ & $\begin{array}{c}5 \\
(3.1 \%)\end{array}$ & \multirow{3}{*}{$\begin{array}{c}0.94 \\
(0.64-1.38)\end{array}$} & \multirow{3}{*}{0.74} & $\begin{array}{c}11 \\
(3.4 \%)\end{array}$ & $\begin{array}{c}7 \\
(3.2 \%)\end{array}$ & \multirow{3}{*}{$\begin{array}{c}0.63 \\
(0.37-1.06)\end{array}$} & & $\begin{array}{c}15 \\
(2.15 \pm 0.56)\end{array}$ & \multirow{3}{*}{0.98} \\
\hline & $h+1 /-$ & $\begin{array}{c}118 \\
(27.7 \%)\end{array}$ & $\begin{array}{c}45 \\
(27.4 \%)\end{array}$ & & & $\begin{array}{c}91 \\
(28.4 \%)\end{array}$ & $\begin{array}{c}62 \\
(28.3 \%)\end{array}$ & & 0.08 & $\begin{array}{c}115 \\
(2.32 \pm 0.63)\end{array}$ & \\
\hline & $h t 1 / h t 1$ & $\begin{array}{c}293 \\
(68.8 \%)\end{array}$ & $\begin{array}{c}114 \\
(69.5 \%)\end{array}$ & & & $\begin{array}{c}219 \\
(68.2 \%)\end{array}$ & $\begin{array}{c}150 \\
(68.5 \%)\end{array}$ & & & $\begin{array}{c}286 \\
(2.23 \pm 0.63)\end{array}$ & \\
\hline
\end{tabular}

*P values of co-dominant models

**Analysis among asthmatic patients

Haplotypes were inferred using the algorithm developed by Stephens et al. (2001). Other haplotypes except MCP3-htl were not analyzed due to equivalent models with SNPs, e.g., $+563 C>T=h t 2,+136 C>G=h t 3,+984 G>A=h t 4$ and $-420 T>C=h t 5$, respectively. (Table 3).

examine the genetic association with asthma and related phenotypes. The frequencies of those four SNPs were 0.020 $(-420 T>C), 0.038(+136 C>G), 0.080 \quad(+563 C>T), 0.035$ $(+984 G>A)$, respectively, in Korean population $(\mathrm{n}=598$,
Table 2). There were five haplotypes (Table 3) and the significant differences in frequencies of SNPs and haplotypes were observed among three ethnic groups (Table 2 and 3). Two rare SNPs $(-420 T>C$ and $+136 C>G)$ were not 
polymorphic in both Caucasian $(\mathrm{n}=50)$ and African American $(\mathrm{n}=50)$. Linkage disequilibrium coefficients $\left(\left|\mathrm{D}^{\prime}\right|\right)$ and $r^{2}$ among SNPs were also calculated (table 4). Complete LDs were observed among all SNPs $\left(\left|\mathrm{D}^{\prime}\right|=1\right)$ along the gene.

The associations of MCP3 polymorphisms (four SNPs and $M C P 3-h t 1)$ with risk of asthma, skin-test reactivity, and total serum IgE levels were analyzed. $M C P 3-h t 2, h t 3, h t 4$ and $h t 5$ were not analyzed because they were equivalent with $M C P 3$ +563C>T (MCP3-ht2), MCP3 +136C>G (MCP3-ht3), and $M C P 3+984 G>A(M C P 3-h t 4), M C P 3-420 T>C(M C P 3-h t 5)$ respectively. The statistic analyses are summarized in Table 3. Although $47 \%$ of power to detect a disease effect was obtained in this study (calculated by $10 \%$ of allele frequency, 450 cases $/ 48$ controls, and 2.0 of odds ratio at significance level of 0.01), no significant associations with asthma development or the intermediate phenotypes were detected in analyses (Table 5).

While MCP3 plays critical roles in anaphylactic reactions as interacting with multiple $\mathrm{CC}$ chemokine receptors, the genetic polymorphisms of $M C P 3$ might not be associated with asthma development and the intermediate phenotypes (skin test and total serum IgE levels).

In summary, we identified four polymorphisms in the human MCP3 gene by direct sequencing of whole gene including 5' flanking region, but we could not find any significant associations of $M C P 3$ variants with risk of asthma and related phenotypes. Although we failed to detect association with asthma, the information concerning genetic polymorphisms of the important $M C P 3$ gene might be useful for host genetic studies of other diseases.

Acknowledgments This work was supported by a grant number M1-0302-00-0073 of National Research Lab. Program as part of National Research and Development Program from the Ministry of Science and Technology of Korea.

\section{References}

Baggiolini, M., Dewald, B. and Moser, B. (1994) Interleukin-8 and related chemotactic cytokines--CXC and CC chemokines. Adv. Immunol. 55, 97-179.

Ben-Baruch, A., Xu, L., Young, P. R., Bengali, K., Oppenheim, J. J. and Wang, J. M. (1995) Monocyte chemotactic protein-3 (MCP3) interacts with multiple leukocyte receptors. C-C CKR1, a receptor for macrophage inflammatory protein-1 alpha/Rantes, is also a functional receptor for MCP3. J. Biol. Chem. 270, 22123-22128.
Hedrick, P. and Kumar, S. (2001) Mutation and linkage disequilibrium in human mtDNA. Eur. J. Hum. Genet. 9, 969972.

Hedrick, P. W. (1987) Gametic disequilibrium measures: proceed with caution. Genetics 117, 331-341.

Humbert, M., Ying, S., Corrigan, C., Menz, G., Barkans, J., Pfister, R., Meng, Q., Van Damme, J., Opdenakker, G., Durham, S. R. and Kay, A. B. (1997) Bronchial mucosal expression of the genes encoding chemokines RANTES and MCP-3 in symptomatic atopic and nonatopic asthmatics: relationship to the eosinophil-active cytokines interleukin (IL)5 , granulocyte macrophagecolony-stimulating factor, and IL-3. Am. J. Respir. Cell Mol. Biol. 16, 1-8.

Kim, M. H., Kim, H. J., Choi, J. Y. and Nahm, D. S. (2003) Transforming growth factor-beta3 gene SfaN1 polymorphism in Korean nonsyndromic cleft lip and palate patients. J. Biochem. Mol. Biol. 36, 533-537.

Livak, K. J. (1999) Allelic discrimination using fluorogenic probes and the 5' nuclease assay. Genet. Anal. 14, 143-149.

Powell, N., Humbert, M., Durham, S. R., Assoufi, B., Kay, A. B. and Corrigan, C. J. (1996) Increased expression of mRNA encoding RANTES and MCP-3 in the bronchial mucosa in atopic asthma. Eur. Respir. J. 9, 2454-2460.

Rojas-Ramos, E., Avalos, A. F., Perez-Fernandez, L., CuevasSchacht, F., Valencia-Maqueda, E. and Teran, L. M. (2003) Role of the chemokines RANTES, monocyte chemotactic proteins- 3 and -4 , and eotaxins- 1 and -2 in childhood asthma. Eur. Respir. J. 22, 310-316.

Stafford, S., Li, H., Forsythe, P. A., Ryan, M., Bravo, R. and Alam, R. (1997) Monocyte chemotactic protein-3 (MCP-3)/ fibroblastinduced cytokine (FIC) in eosinophilic inflammation of the airways and the inhibitory effects of an anti-MCP-3/FIC antibody. J. Immunol. 158, 4953-4960.

Stephens, M., Smith, N. J. and Donnelly, P. (2001) A new statistical method for haplotype reconstruction from population data. Am. J. Hum. Genet. 68, 978-989.

Xu, L. L., McVicar, D. W., Ben-Baruch, A., Kuhns, D. B., Johnston, J., Oppenheim, J. J. and Wang, J. M. (1995) Monocyte chemotactic protein-3 (MCP3) interacts with multiple leukocyte receptors: binding and signaling of $\mathrm{MCP} 3$ through shared as well as unique receptors on monocytes and neutrophils. Eur. J. Immunol. 25, 2612-2617.

Ying, S., Meng, Q., Zeibecoglou, K., Robinson, D. S., Macfarlane, A., Humbert, M. and Kay, A. B. (1999) Eosinophil chemotactic chemokines (eotaxin, eotaxin-2, RANTES, monocyte chemoattractant protein-3 (MCP-3), and MCP-4), and $\mathrm{C}-\mathrm{C}$ chemokine receptor 3 expression in bronchial biopsies from atopic and nonatopic (Intrinsic) asthmatics. J. Immunol. 163, 6321-6329.

Zhang, J. and Li, K. (2003) On-off regulation of 3' exonuclease excision to DNA polymerization by $\mathrm{Exo}^{+}$polymerase. $J$. Biochem. Mol. Biol. 36, 525-528. 